\title{
Antielegia aos pósteros
}

\section{Carlos Nejar*}

Porto Alegre, Brasil

carpinejar@terra.com.br

1

Nenhuma fala

pode

interromper

a brisa.

E a água

caiu na palavra,

caiu da água.

E era de dizer

águas, água.

E a noite move

o firmamento

numa fala arredia.

E o que é água:

alma.

Tudo pesa

nada.

De subir

na chama,

tudo pesa

água.

* Poeta, tradutor, romancista e ensaísta. Membro da Academia Brasileira de Letras. 
Ventos

ventos

ventos

todos caem.

Para podermos subir

E após, descer descer

até regiões imotas.

E descendo, talvez

cheguem aos pósteros

nossa agonia, os fonemas

da democracia

com a cabeça emborcada

num trovão, entre

as vogais da lua.

Os pósteros

desconfiarão

dos mais pósteros

que eles. E não

acharão mais dúvidas

que nós diante

deste Planeta

inconsolável.

Se ainda houver

Planeta.

Recebido em: 10/09/2018.

Aprovado em: 10/10/2018. 